\title{
Notas lukacsianas sobre a decadência ideológica da burguesia
}

\author{
Ricardo Lara \\ Universidade Federal de Santa Catarina (UFSC)
}

\section{Notas lukacsianas sobre a decadência ideológica da burguesia}

Resumo: Este artigo traz reflexão sobre a categoria teórica decadência ideológica presente no pensamento de Lukács para, com isso, oferecer elementos para compreensão da crítica à especialização das ciências sociais. Procura, ainda, indicar que a categoria decadência ideológica resgata a conexão, na crítica marxista, entre a força material e a construção ideológica da ordem social capitalista.

Palavras-chave: Decadência ideológica. Crítica marxista. Capitalismo. Ideologia.

\section{Lukacksian Notes about the Ideological Decadence of the Bourgeoisie}

Abstract: This article reflects on the theoretical concept of ideological decadence in the thinking of Lukács to provide elements for an understanding of the criticism of the specialization of the social sciences. It also seeks to indicate that the theoretical concept of ideological decadence revives the connection, in the Marxist criticism, between the material strength and ideological construction of the capitalist social order.

Keywords: Ideological decadence. Marxist criticism. Capitalism. Ideology. 


\section{Introdução}

A luta ideológica é intrínseca à sociedade de classes sociais antagônicas. A ideologia ${ }^{1}$ emerge no momento em que os sujeitos tomam consciência dos conflitos sociais e criam os meios para combatê-los. Na produção de ideias e, por conseguinte, no conhecimento científico também estão situadas as altercações ideológicas, por isso torna-se relevante o resgate da categoria decadência ideológica desenvolvida por Georg Lukács, principalmente após a consolidação das diversas áreas do conhecimento (sociologia, história, economia, filosofia, psicologia), com suas metodologias particulares que, em muitos casos, esforçam-se para diluir a perspectiva teórico-filosófica que apresente a possibilidade da crítica social aliada à transformação social.

O caráter antiontológico na teoria social é uma das questões mais marcantes diante da especialização das ciências sociais, nesse caso o marxismo de Lukács é uma tendência salutar, como também pouco conhecida. O marxista húngaro e suas críticas no campo das ciências do espírito, principalmente em relação à especialização das ciências sociais, são objetadas ou mesmo desconhecidas. Nisto reside a necessidade de retomar a crítica lukacsiana, ainda mais porque a leitura de Lukács da obra de Marx centra-se na perspectiva que entende a teoria social marxiana como uma ontologia do ser social.

Lukács (1969, p. 15) apresentou a proposta de resgatar os fundamentos ontológicos da teoria social de Marx:

[...] o objeto da ontologia marxista, diferentemente da ontologia clássica e subsequente, é o que existe realmente: a tarefa é a de investigar o ente com a preocupação de compreender o seu ser e encontrar os diversos graus e as diversas conexões em seu interior.

O marxista húngaro foi ousado ao discutir ontologia em pleno século 20. Para a maioria dos cientistas sociais, filósofos e demais estudiosos da sociedade humana, a ontologia não se coloca mais como possibilidade diante da situação da ciência e da filosofia ${ }^{2}$ contemporânea, pois a divisão social do trabalho se desenvolveu com tamanha radicalidade que as diversas áreas do saber têm condições suficientes para elaborar conhecimentos a partir de suas próprias metodologias com interesses específicos. Para muitos, senão para a maioria, o estudo do ser social em sua condição de existência determinada historicamente e analisada a partir da totalidade da vida social não é mais cabível. Contra essa direção predominante nas ciências do espírito, a concepção teórica de Lukács apresenta importante perspectiva para afirmação da ontologia:

A percepção da ontologia em Marx fornece a Lukács os elementos passíveis de estabelecer, de uma vez por todas, a ruptura com o predomínio da gnosiologia e da epistemologia em nossos tempos. Suas reflexões partem da crítica fundamental que postula que, em Marx, o tipo e o sentido das abstrações, dos experimentos ideais, são determinados não a partir de pontos de vista gnosiológicos ou metodológicos (e tanto menos lógicos), mas a partir da própria coisa, isto é, da essência ontológica da matéria tratada (VAISMAN; FORTES, 2010, p. 21).

Ao considerar o pensamento de Marx como a análise dos processos de produção e reprodução da vida social, a ontologia desenvolvida por Lukács se esforça para reapresentar, sem as interpretações parciais de um campo específico do conhecimento, as principais categoriais teóricas da concepção materialista-dialética que parte "do momento em que os homens são representados como atores e autores de sua própria história" (MARX, 2009, p. 131). Nesse caso, a possibilidade da emancipação humana está presente na ontologia lukacsiana como condição de superação da sociedade de classes.

Em oposição às teorias que objetivam justificar a acumulação capitalista e naturalizar a exploração da força de trabalho, a categoria decadência ideológica oferece importantes elementos para a compreensão das ideologias que se propõem neutras e antiontológicas, presentes no pensamento social com seus apelos ao fragmentário, ao efêmero e, principalmente, ao esquecimento das análises sobre a luta de classes, o trabalho alienado, a propriedade privada dos meios fundamentais de produção, a revolução social. Várias ramificações das ciências do espírito esforçam-se para desenvolverem tradições científicas apologéticas e, em consequência, um discurso ideológico que busca, a qualquer custo, justificar as contradições sociais e negar uma "concepção da História que veja na luta de classes a força motriz do desenvolvimento e no capitalismo uma forma social transitória" (LUKÁCS, 1968, p. 74).

Portanto, resgatar a categoria decadência ideológica, retomar a crítica marxiana como resistência teórico-ideológica são desafios necessários que se tornam, a cada instante, mais difíceis no âmbito da lógica produtivista da elaboração do conhecimento ancorado na difusão de metodologias particulares que negam as categorizações teóricas (racionalidade, sujeito, história, emancipação, humanidade e progresso) da tradição moderna. Á orientação marxiana é importante diante do atual contexto de miséria ideológica e crise do capital 
(PINASSI, 2009), pois as graves e globalmente intensificadas contradições da ordem social não podem ser deixadas permanentemente sob o manto da mistificação metodológica e ideológica (MÉSZÁROS, 2009).

\section{A decadência ideológica}

A decadência ideológica denunciada por Marx e Engels e interpretada por Lukács ${ }^{3}$, é o período claramente marcado pela tentativa de os ideólogos burgueses produzirem conhecimentos que têm como premissa a evasão da realidade social, com explícitas intencionalidades de conservação da ordem do capital. Lukács analisa o desenvolvimento da apologética burguesa e a mistificação do pensamento social, demonstra a relação entre as distorções espirituais da ideologia contrarrevolucionária presente nas ciências do espírito e, por conseguinte, a evolução teórico-ideológica da sociedade capitalista como processo de amenização nas análises sociais que criticassem a ordem social dominante.

O processo de decomposição das teorias clássicas sobre a vida social ocorre aproximadamente entre os anos de 1820 e 1840, sendo Hegel o último grande pensador da filosofia burguesa revolucionária, Adam Smith e David Ricardo os derradeiros representantes da economia política clássica e Robert Owen, Saint-Simon e Charles Fourier os últimos socialistas utópicos ${ }^{4}$. A teoria social que se preocupava com a totalidade da vida social, interessada em descobrir a verdade do mundo, começa a ser substituída pela apologética. Esse processo ocorre com a tomada do poder político pela burguesia e, simultaneamente, a luta de classes entra em cena, com o protagonismo emergente do proletariado.

O medo do movimento revolucionário de 1848 interrompe o ciclo progressista da burguesia e de suas possibilidades teóricas em dar respostas que expressassem a visão de mundo ascendente do projeto burguês, pois sua perspectiva teórica choca-se com os limites do projeto de sociedade. Ou seja, entre a herança teóricocultural emancipadora e a manutenção da ordem, a burguesia opta pelo segundo, dando origem ao "pensamento da ordem", berço perfeito para o nascimento das ciências sociais especializadas.

Em nível histórico-universal, a experiência de 1848 demonstrou os limites reais do projeto sociopolítico conduzido pela burguesia - a 'liberdade' deve restringir-se à liberdade de concorrer no mercado, a 'igualdade' esgota-se na formalidade jurídica e a 'fraternidade' se resolve na retórica e no moralismo. O 'projeto de emancipação humana', nestes limites, não desborda o terreno da 'emancipação política', tal como Marx mesmo o vislumbrou em 1844. A partir desse marco, o protagonismo burguês centra-se na conservação da ordem. [...] A burguesia, enquanto classe, perde o interesse e a capacidade de fazer avançar a socialidade para além dos limites da lógica de acumulação e valorização do capital, em razão da qual se operou a emancipação política e se estabeleceu originalmente a figura do 'cidadão'. A dimensão essencial da emancipação humana só terá sentido para um outro sujeito histórico, cuja emersão primeira verifica-se em 1848: o proletariado. O significado de 1848 é precisamente este: com a derrota das aspirações democráticopopulares, determinada pelo comportamento de classe da burguesia, o proletariado se investe, em nível histórico-universal, como o herdeiro das tradições libertárias e humanistas da cultura ocidental, constituindo-se como o sujeito de um novo processo emancipador, cuja condição prévia, histórico-concreta, é a ruptura mais completa com a ordem do capital. Assim, no plano prático-político, a revolução de 1848 tem um significado inequívoco: trouxe à cena sociopolítica uma classe que, a partir daqueles confrontos, pode aceder à consciência dos seus interesses específicos - viabilizou a emergência de um projeto sociopolítico 'autônomo', próprio, do proletariado; mais exatamente: propiciou a autopercepção 'classista' do proletariado (NETTO, 1998, p. 19-20).

A partir de $1848^{5}$, inaugura-se o período de segurança econômica e política, sob a ordem social da burguesia, em que a filosofia satisfaz-se com o agnosticismo oscilante entre o "materialismo envergonhado" e o "solipsismo" (LUKÁCS, 1967). O pensamento social após 1848, com poucas exceções, foi se adequando às circunstâncias históricas do modo de produção capitalista. As explicações sobre as relações sociais oferecidas pelas ciências do espírito, a partir da consolidação da sociedade burguesa, com poucas reservas, colaboraram para a compreensão do homem e da sociedade como partes isoladas da processualidade sócio-histórica.

No âmbito da teoria social, a visão de progresso defendido pela concepção científica da burguesia é quase totalmente ignorada a partir de 1848. As leis tendênciais da história e a visão de transitoriedade passam a ser inquietações pretéritas do pensamento burguês, o proletariado como classe universal (classe para si) é objetada em seu protagonismo histórico. Nesse contexto, principia-se a orientação subjetivista e conservadora da burguesia que se tornou contrarrevolucionária, em detrimento dos fatos reais da história. Para Lukács (1968, p. 99): 
A decadência ideológica surge quando as tendências da dinâmica objetiva da vida cessam de ser reconhecidas, ou são inclusive mais ou menos ignoradas, ao passo que se introduzem em seu lugar desejos subjetivos, vistos como a força motriz da realidade.

O processo de decomposição da filosofia e da economia política clássica (concepções teóricas que se preocupavam com o conjunto da vida social) instala-se no pensamento social porque o "movimento histórico objetivo contradiz a ideologia burguesa" (LUKÁCS, 1968, p. 99). A concepção teórico-ideólogica burguesa, a partir de 1848, preocupa-se em amenizar os conflitos sociais e retirar das surgentes ciências do espírito qualquer compreensão ou categorização teórica que analise a essência da acumulação capitalista $^{6}$. Neste caso, a compreensão científica mais objetada foi à teoria do valor-trabalho. No campo da economia, surge a teoria da utilidade marginal com a Escola Austríaca de Carl Menger e outros, uma nova concepção que pretende resolver os problemas da burguesia com o marxismo e a teoria da mais-valia. A teoria da utilidade marginal ${ }^{7}$ "cortou os últimos laços que uniam a economia à tradição da economia política clássica. O elemento principal desta ruptura consiste na atribuição de significação subordinada ao trabalho". O princípio do trabalho que a burguesia liberal defendeu contra a propriedade feudal passa a representar um perigo quando o proletariado entra em cena: "Nisto reside a principal razão da mudança de posição da teoria econômica" (KOFLER, 2010, p. 229).

A vocação apologética de negação das contradições da vida real surge como imperativo da burguesia para assegurar seu poder material e espiritual, com isso, o que se procede no âmbito do pensamento social é observado, atentamente, por Marx (2002, p. 24):

Não interessava mais saber se este ou aquele teorema era verdadeiro ou não; mas importava saber o que, para o capital, era útil ou prejudicial, conveniente ou inconveniente, o que contrariava ou não a ordenação policial. Os pesquisadores desinteressados foram substituídos por espadachins mercenários, a investigação científica imparcial cedeu seu lugar à consciência deformada e às intenções perversas da apologética.

Marx endereçava acertada crítica à ideologia decadente, que se instaurava no espírito da sociedade. Cerceada pelo conflito de classes, a burguesia tinha necessidade teórico-ideológica de assegurar a ordem social e elaborar a retórica oficial sobre as contradições sociais causadas pelo capitalismo. A ideologia revolucionária de 1789 apresenta, após 1848, traços decadentes. No momento de solidificação do poder burguês, não era mais interessante manter o caráter transformador da ideologia burguesa. A partir do período que foi assegurado hegemonicamente às conquistas da burguesia, o que interessava era formular respostas justificadoras aos problemas decorrentes do desenvolvimento capitalista e ocultar os conflitos de classes procedentes da relação antagônica entre capital e trabalho.

Na argumentação de Lukács (1968, p. 62), a diferença entre os pensadores clássicos da burguesia e os seus herdeiros reside "apenas" em que os ideólogos anteriores forneceram resposta sincera e científica, mesmo se incompleta e contraditória, ao passo que a decadência foge da expressão da realidade e mascara a fuga mediante o recurso ao "espírito objetivo" ou a ornamentos românticos. As ciências do espírito, em muitos casos, surgem acríticas, não vão além da descrição dos fenômenos, permanecem na imediaticidade e recolhem empiricamente os dados fragmentados da realidade social para analisá-los e manipulá-los pela união do ecletismo e relativismo.

No processo de consolidação do poder burguês, o saber intencionado em desvendar as reais contradições da sociedade começa a ser substituído pelo saber compromissado com as instituições oficiais capitalistas. Até então, a história tinha seu curso transitório e processual, após1848 a história torna-se "ocorrência do passado". A história torna-se efetivamente uma coleção de fatos mortos ${ }^{8}$. A apologética, revestida de ciência do espírito imparcial e neutra, assume a direção na elaboração de conhecimentos através das ciências especializadas (sociologia, história, economia, filosofia) que trabalham para justificar a ordem do capital. Diante desse cenário, Pinassi (2009, p. 16) comenta:

Para Marx e também Lukács, o 'momento predominante' ao conceito de 'decadência ideológica' coincide com a conclusão dos esforços revolucionários da burguesia e o início da sua hegemonia, da 'sua localização no comando da estrutura do capital'. Nessa medida, o sentido da 'decadência ideológica' é a contraface absolutamente necessária - do brutal desenvolvimento material e tecnológico deflagrado a partir daí; e o seu comprometimento passa a se estabelecer tão somente com a reprodução incessante da estrutura sociometabólica do capital, mitigando as resistências e amaciando o curso do controle.

A categoria decadência ideológica, elaborada por Lukács (1968, p. 52), designa o estado espiritual da burguesia após 1848 . O que temos, com a evolução do pensamento social, é a: 
[...] liquidação de todas as tentativas anteriormente realizadas pelos mais notáveis ideólogos burgueses, no sentido de compreender as verdadeiras forças motrizes da sociedade, sem temor das contradições que pudessem ser esclarecidas; essa fuga numa pseudo-história construída a bel-prazer, interpretada superficialmente, deformada em sentido subjetivista e místico, é a tendência geral da decadência ideológica.

Lukács (1967) oferece indicações sobre a evolução da concepção social moderna, que pode ser compreendida a partir de três estágios. O primeiro vai até 1848, período da filosofia e economia clássica burguesa. O pensamento filosófico dessa época era uma forma aberta para elaboração de um saber verdadeiramente científico, de tal modo que os seus pensadores sustentavam a plena cognoscibilidade do mundo. Temos como referências as obras de Hegel, Kant, Locke, Helveltius, Holbach, Adam Smith e David Ricardo, astutos representantes do pensamento burguês. A filosofia e a economia política tinham na vida social e no progresso as referências para a elaboração teórica. Elencamos algumas características desse momento: a) a origem da expressão mais elevada da concepção de mundo, isto é, revolta da burguesia contra a sociedade feudal em declínio; b) o pensamento social que codifica os princípios últimos e a concepção geral do mundo; c) o movimento progressivo e libertador que reformou a sociedade; $d$ ) a transformação da lógica das ciências naturais e sociais; e) as intervenções da filosofia nos grandes problemas concretos da humanidade, nas ciências naturais e sociais; f) o papel da filosofia era de universalidade e "fermento" das ciências; g) a filosofia comprometida com a missão histórica da revolução burguesa; h) na economia política, o trabalho é descoberto e analisado como fonte de valor e; i) os economistas clássicos descobriram a eficiência da produção material capitalista (LUKÁCS, 1967, p. 31-33).

O segundo estágio, fase inicial da decadência ideológica, ocorre a partir de 1848 com a entrada autônoma do proletariado $^{9}$ - em plano histórico-universal - na arena política e vai até a emergência do imperialismo, etapa que emergem tendências teórico-ideológicas de evasão do pensamento da realidade social, com explícita intencionalidade de manutenção da ordem. A concepção teórica expressa-se no agnosticismo, que derrui a crença no poder da razão de conhecer a essência ${ }^{10}$ verdadeira do mundo, levando a reflexão a abandonar as grandes temáticas sócio-históricas.

Em relação ao período da decadência ideológica e ao afastamento intencional da burguesia da razão sócio-histórica, Coutinho (1972, p. 22) afirma:
Em oposição às teorias que objetivam justificar a acumulação capitalista e naturalizar a exploração da força de trabalho, a categoria decadência ideológica oferece importantes elementos para a compreensão das ideologias que se propõem neutras e antiontológicas, presentes no pensamento social com seus apelos ao fragmentário, ao efêmero e, principalmente, ao esquecimento das análises sobre a luta de classes, o trabalho alienado, a propriedade privada dos meios fundamentais de produção, a revolução social.

[...] as contradições capitalistas tornaram-se explosivas, encarnação e produto dessas contradições, o proletariado surge na história como força social autônoma, capaz de resolver em sentido progressista os limites e as antinomias do sistema capitalista. Indicar a realidade como algo essencialmente contraditório significa, doravante, fornecer armas teóricas ao movimento anticapitalista da classe operária. De crítica da realidade em nome do progresso, do futuro, das possibilidades reprimidas, o pensamento burguês transforma-se numa justificação teórica do existente. Em proporções cada vez maiores, a história e a economia perdem sua anterior importância filosófico-ontológica, deixando de desenhar um papel significativo na elaboração da concepção de mundo. E, com isso, perde-se a possibilidade de apreender a essência da realidade humana: a filosofia da decadência torna-se, cada vez mais, um pensamento imediatista, centrado nas aparências fetichizadas da realidade.

A apreensão imediatista e a-histórica é o mote da concepção científica da decadência, a objetividade social é ignorada. As relações de produção e reprodução da vida social, o desenvolvimento histórico, 
social e econômico não são considerados no seu percurso transitório na elaboração das categorias teóricas. A atividade humana, a práxis social, em todas as suas determinações, é progressivamente afastada do domínio da racionalidade.

Sobre o início do período da ideologia decadente, elencamos: a) a renúncia do pensamento social com preocupações de dar respostas para as mudanças sociais que ocorrem na produção e reprodução da vida social; b) o não questionamento ao capitalismo; c) a desconsideração das descobertas das ciências naturais que questionam os dogmas religiosos; d) o neokantismo e o positivismo como tendências dominantes; e) a filosofia dominante da época é a filosofia de professores e torna-se ciência especializada; f) a filosofia renuncia à sua antiga missão social, cessa de ser expressão, no plano espiritual, dos grandes interesses históricos da burguesia e abandona o problema ideológico; g) o pensamento social como "guarda-fronteira", ou seja, explicação e justificação da vida burguesa; h) a emergência dos intelectuais burocratizados que fazem parte do aparelho do Estado; i) a radicalização da divisão social do trabalho ${ }^{11}$ e a emergência dos intelectuais com suas propostas de métodos e independência relativa para suas "ciências" (LUKÁCS, 1967, p. 33-35).

Segundo Netto (1978, p. 18), a decadência ideológica é a "guarda-fronteiras" das ciências sociais; "o seu papel limita-se à vigilância 'para que ninguém ouse tirar das ciências econômicas e sociais conclusões que poderiam desacreditar o sistema"”.

A principal obra de Marx, $O$ capital, sofreu com a ideologia decadente de sua época. Lukács, na Ontologia do ser social, especificamente no capítulo referente aos princípios ontológicos fundamentais de Marx, comenta sobre a diferença da obra de Marx em relação aos seus contemporâneos, pois os intelectuais das tendências dominantes da época de $O$ capital não compreendiam o método de Marx, que tem como ponto de partida e chegada a crítica da produção e reprodução da vida social, na sua totalidade. De acordo com Lukács (1979, p. 30, grifo nosso):

Essa concepção geral - ainda que resulte de modo orgânico da crítica e da superação materialistas do método hegeliano - era de 'tal modo estranha às tendências dominantes da época que não foi compreendida como método nem pelos adversários nem pelos seguidores'. Depois de 1848, depois do colapso da filosofia hegeliana e, sobretudo, a partir do 'início da marcha triunfal do neokantismo e do positivismo, os problemas ontológicos deixaram de ser compreendidos'. Os neokantianos eliminaram da filosofia até mesmo a incognoscível coisa em-si, enquanto para o positivismo a percepção subjetiva do mundo coincide com a sua realidade. Não é de surpreender, portanto, que - submetida a tais influências - a 'opinião pública científica julgue a economia de Marx como uma ciência particular' que, na prática da 'exata' divisão do trabalho, termina por revelar-se metodologicamente inferior ao modo 'axiologicamente neutro' de apresentar as coisas, ou seja, ao modo burguês.

O terceiro estágio de desenvolvimento da concepção científica burguesa ocorre com a entrada do capitalismo em sua fase imperialista ${ }^{12}$. É o período em que se acirram as contradições sociais ${ }^{13}$. Nesse estágio do capitalismo, ao mesmo tempo em que se intensificam as contradições, emergem elementos indispensáveis que possibilitam tanto uma diminuição da percepção da brutalidade da chamada crise geral do sistema, como também, por outro lado, congregam esforços na tentativa de reação à teoria social que responde pela práxis do proletariado (LUKÁCS, 1967). Desta maneira, sobre os limites do agnosticismo anterior, floresce uma estruturação filosófica em torno do irracionalismo que mostra sua impossibilidade social e teórica de defesa da ordem social dominante, e que também não questiona o modo de produção capitalista, mas faz emergir uma falsa solução, a terceira via: nem materialismo, nem idealismo. "Deste modo, inaugura-se no patamar epistemológico a pseudo-objetividade dos mitos e a intuição como instrumento do conhecimento verdadeiro" (SOUSA, 2005, p. 60). Assim, a filosofia torna-se interessante para os intelectuais mais entendidos. No âmbito da filosofia destaca-se: a) indiferença da burguesia com a filosofia; b) oposição à filosofia universitária, sem maiores repercussões no plano da crítica teórica; c) pensadores da filosofia do imperialismo fora da Universidade (Nietzsche, Spengler, Keyserling, Klages); d) crescimento dos intelectuais que fazem filosofia para seu próprio uso; e) elaboração das doutrinas ideológicas com toda liberdade; f) emergência do fascismo (LUKÁCS, 1967, p. 36-37).

A elaboração da terceira via, no plano da filosofia, oferece argumentos para atacar a clássica polêmica entre materialismo e idealismo. Advém:

[...] una luta real contra el materialismo con ataques aparentes contra el idealismo se arroga la pretensión de presentar una 'nueva' filosofia que se sobrepone por fin a la falsa contraposición de materialismo e idealismo, descubriendo en el campo filosófico una 'terceira vía'. Y, como esta afinidad abarca sobre poco más o menos todos los problemas esenciales de la filosofia, debe servir de base para enjuiciar el pragmatismo (LUKÁCS, 1959, p. 18). 
A terceira via, como oportunidade de salvar o idealismo filosófico subjetivo, "vai de Mach e Nietzsche até o existencialismo e que consiste em se proclamar neutro também frente ao materialismo e ao idealismo, que se pretende ultrapassar, do ponto de vista da teoria do conhecimento" (LUKÁCS, 1967, p. 16). Esse processo de degeneração da racionalidade moderna, com grande ênfase no determinismo social, vai tomar forma concreta com o fascismo. $\mathrm{O}$ "fascismo traduz para a linguagem do capitalismo reacionário dos trustes, ou melhor, para a linguagem da demagogia nacional e social da reação, todas as 'conquistas' da filosofia do estágio imperialista" (LUKÁCS, 1967, p. 37).

Os filósofos do terceiro estágio da concepção social burguesa, fase do imperialismo, conhecem cada vez menos as relações sociais e econômicas da sociedade, desconsideram a realidade sócio-histórica como pressuposta à reflexão teórica, negam radicalmente o caráter revolucionário do proletariado, ignoram a teoria do valor-trabalho. O caráter antiontológico da ideologia decadente consiste principalmente no combate à dialética, à historicidade e à totalidade ${ }^{14}$; as concepções e interpretações se restringem ao fenômeno e desconsideram as suas conexões reais.

Lukács (1959) discorre sobre a trajetória do irracionalismo, fruto da evolução do pensamento social burguês, desdobramento da decadência ideológica. O irracionalismo, fenômeno internacional sobre todo o período imperialista, é a resposta do pensamento reacionário diante do desenvolvimento contraditório - produção coletiva e apropriação privada da riqueza - das forças produtivas da sociedade capitalista. Para Lukács (1959, p. 8-9):

[...] las diferentes etapas del irracionalismo nacen como otras tantas respuestas reaccionarias a los problemas planteados por la lucha de clases. El contenido, la forma, el método, el tono etc., de sus reacciones en contra del progreso social no los determina, por tanto, aquella dialéctica interna y privada del pensamiento, sino que los dictan, por el contrario, el adversário, las condiciones de la lucha que a la burguesía reaccionaria le vienen impuestas desde fuera. Conviene retener esto, como principio fundamental que preside el desarrollo del irracionalismo. Lo que no significa que el irracionalismo, dentro de este marco social así determinado, no muestre uma unidad ideal. Antes al contrario. De ese carácter suyo se desprende, precisamente, el que los problemas de contenido y de método por él planteados presentan uma fuerte cohesión, revelan una sorprendente (y estrecha) unidad. El desprecio del entendimento y la razón, la glorificación lisa y llana de la intuición, la mitomania etc., son otros tantos motivos que podemos descubrir sin dificultad, sobre poco más o menos, en todo irracionalista.

Em síntese, os três estágios apresentam tendências presentes, com maior ou menor incidências, na concepção científica burguesa que levaram água ao moinho das ciências sociais particulares. As categorias fundamentais do pensamento moderno - razão, historicismo e humanismo ${ }^{15}$ - tendem a se esgotar no âmbito das ciências do espírito da ideologia decadente. A preocupação com o progresso e o futuro, bem como a crença na razão como meio de compreender e transformar a realidade social (herança do iluminismo) vão se esgotando ao longo do avanço da decadência ideológica. O irracionalismo é seu resultado e evidencia a total descrença na humanidade e a aversão à possibilidade radical da emancipação humana pela lógica do trabalho.

\section{Considerações finais}

O capitalismo, no seu sociometabolismo, apresentou mudanças materiais (econômico-sociais) e espirituais (ideológico-culturais) intensas na história da humanidade. O processo de consolidação da hegemonia material e espiritual da burguesia impôs enorme transfiguração das ideologias clássicas do século 18 em ideologias apologéticas no século $19 \mathrm{e}$, por conseguinte, desaguou no irracionalismo do século 20. Portanto, o significado da decadência ideológica deve ser averiguado na divisão social capitalista do trabalho, observada as suas consequências sociais e culturais. Podemos afirmar que a decadência ideológica se sustenta sobre a forma de sociabilidade instrumental e universal necessária ao desenvolvimento do modo de produção capitalista, à formação do grande mercado, ao nascimento das nacionalidades advindas do período das grandes e pequenas revoluções burguesas, radicais e passivas, clássicas, tardias e hipertardias, fase em que o capitalismo consolidava a positividade da sua dominação social (PINASSI, 2009).

Parte significativa do pensamento burguês renegou em e a partir de 1848 a instauração de sentido para a vida social ao extrair da legalidade histórica a sua condição sine qua non de transitoriedade ${ }^{16}$. "A crítica endereçada por Marx à "decadência ideológica" concentra-se na tarefa de revelar o espírito pequeno-burguês que se esconde por trás da retórica superficial pomposa" (LUKÁCS, 1968, p. 98). A decadência ideológica desvenda a apologética burguesa, justificadora do desenvolvimento capitalista do final da segunda metade do século 19, que se ancora no período do imperialismo, e se concretiza nas crises do capital do século 20. Nessa processualidade social, surgem os defensores da ordem social, com suas teorizações do 
"pleno emprego", do "estado de bem-estar social", sustentadores da apologética burguesa. A crítica marxiana que se desenvolve com a categoria decadência ideológica desvenda o poder da ideologia, revestida de apologética, que oferece sustentação para a acumulação capitalista. A categoria decadência ideológica revela a crítica imamente da totalidade social, resgata a conexão entre força material e construção ideológica do sistema do capital, oferece a possibilidade da crítica, genuína e fecunda, que restabelece a perspectiva ontológica histórico-materialista.

A crítica marxiana-lukacsiana captura a lógica do real e, ao contrário do saber apologético, a história deixa de ser uma coleção de fatos mortos. Marx, com a contribuição de Engels, transformou radicalmente todos os fenômenos da sociedade e do homem em problemas históricos, mostrando concretamente o substrato real do desenvolvimento social e tornando-o metodologicamente fecundo (LUKÁCS, 1979). Essa concepção de realidade tem respaldo na história, não como um conjunto de fatos mortos, como quer o pensamento decadente, mas na interpretação do "passado em sentido ontológico e não no sentido da teoria do conhecimento [...]. Ontologicamente, ao contrário, o "passado nem sempre é algo passado, mas exerce uma função no presente'" (LUKÁCS, 1969, p. 30). Nesse caso, o ponto de partida não é aleatório, muito menos pré-determinado, é aproximação cognoscente da práxis humana.

O pensamento burguês, após a decadência ideológica, em muitos casos, apresenta tendências que não se preocupam em construir conhecimentos que levam em consideração a modernidade social ${ }^{17}$. O pensamento social decadente faz das ciências do espírito um mecanismo irracional que nega o desenvolvimento sócio-histórico e evita produzir o saber que tenha como pressuposto o mundo da atividade concreta e sensível do homem. Por fim, como bem lembrou Lukács (1959, p. 4), ao abordar o irracionalismo, "no hay ninguna ideologia "inocente"”, portanto, a decadência ideológica é uma referência conceitual imprescindível na atualidade, principalmente diante das ideologias que pregam o "fim da história", o "fim do trabalho", o "fim da ideologia".

\section{Referências}

COUTINHO, C. N. O estruturalismo e a miséria da razão. Rio de Janeiro: Paz e Terra, 1972. HOBSBAWM, E. A era do capital. Tradução de Luciano Costa Neto. São Paulo: Paz e Terra, 2010. KOFLER, L. História e dialética: estudos sobre a metodologia da dialética marxista. Rio de Janeiro: Editora UFRJ, 2010. LÊNIN, V. Imperialismo, fase superior do capitalismo. In:___. Obras escolhidas. São Paulo: Alfa-Omega, 1982. (v. 1). LUKÁCS. G. El asalto a la razón: la trayectoria del irracionalismo desde Schelling hasta Hitler. Traducción de Wenceslao Roces. México-Bueno Aires: Fondo de Cultura Económica, 1959. . Existencialismo ou marxismo. Tradução de José Carlos Bruni. São Paulo: Senzala, 1967. . Marxismo e teoria da literatura. Tradução de Carlos Nelson Coutinho. Rio de Janeiro: Civilização Brasileira, 1968. . Conversando com Lukács. Tradução de Giseh Vianna Konder. São Paulo: Terra e Paz, 1969.

. Ontologia do ser social: os princípios ontológicos fundamentais de Marx. Tradução de Carlos Nelson Coutinho. São Paulo: Ciências Humanas, 1979. . Sociologia. Tradução de José Paulo Netto. São Paulo: Ática, 1981. (Coleção Grandes Cientistas Sociais, n. 20). . Prolegômenos para uma ontologia do ser social. Tradução de Lya Luft e Rodnei Nascimento. São Paulo: Boitempo, 2010.

MARX, K. Miséria da filosofia. Tradução de José Paulo Netto. São Paulo: Expressão Popular, 2009.

. O capital: crítica da economia política. Tradução de Reginaldo Sant'anna. Rio de Janeiro: Civilização Brasileira, 2002.

MARX, K.; ENGELS, F. Manifesto do partido comunista. Prólogo de José Paulo Netto. São Paulo: Cortez, 1998.

MÉSZÁROS, I. Estrutura social e formas de consciência: a determinação social do método. Tradução de Luciana Pudenzi et al. São Paulo: Boitempo, 2009.

NETTO, J. P. Lukács e a crítica da filosofia burguesa. Lisboa: Seara Nova, 1978. v. 1. . Lukács: tempo e modo. In: LUKÁCS, G. Sociologia. São Paulo: Ática, 1981. (Coleção Grandes Cientistas Sociais, n. 20).

. Elementos para uma leitura crítica do Manifesto Comunista. In: MARX, K.; ENGELS, F. Manifesto do partido comunista. São Paulo: Cortez, 1998.

PINASSI, M. O. Da miséria ideológica à crise do capital: uma reconciliação histórica. São Paulo: Boitempo, 2009. (Coleção Mundo do Trabalho).

SOUSA, A. A. S. de. Pós-modernidade: fim da modernidade ou mistificação da realidade contemporânea? Temporalis, Brasília, ano 5 , n. 10 , p. $51-81,2005$.

VAISMAN, E.; FORTES, R. V. Prefácio. In: LUKÁCS. G. Prolegômenos para uma ontologia do ser social. Tradução de Lya Luft e Rodney Nascimento. São Paulo: Boitempo, 2010. 


\section{Notas}

1 A ideologia "é antes de tudo uma forma de elaboração ideal da realidade que serve para tornar a práxis social dos homens consciente e operativa. [...] Somente depois de se tornar veículo teórico ou prático para combater conflitos sociais, quaisquer que sejam, grandes ou pequenos, episódicos ou decisivos para o destino da sociedade, eles são ideologia” (LUKÁCS, 2010, p. 38).

2 Para Lukács (2010, p. 140): “A cientificidade 'pura' das pesquisas singulares perdeu cada vez mais seu contato fortemente com a filosofia. O positivismo e o neopositivismo que passaram a dominar na pesquisa reduziram cada vez mais seus traços filosoficamente generalizantes, para funcionar como um compêndio puramente prático, meramente eficiente, das pesquisas singulares, como uma metodologia subordinada a elas. Essa separação decisiva entre filosofia e ciência particular resultou em um espaço ilimitado para esta última, aparentemente só limitada por postulados de 'exatidão'. Essa 'liberdade', porém, é simplesmente o outro lado de seu sempre mais amplo colocar-se ao serviço da produção material e de sua organização racional para o mercado. Essa situação resulta em uma unidade peculiar, peculiarmente intrincada de total liberdade metodológica nas questões particulares a ser diretamente pesquisadas, e de uma ligação bastante estrita com sua efetividade, considerada do ponto de vista do mercado."

3 José Paulo Netto (1981,p. 50) organiza em três níveis as contribuições de Lukács para a tradição marxista: político-ideológico, filosófico e estético. “Ao nível político-ideológico, Lukács reintroduziu, no pensamento marxista, a denominação precisa do fenômeno da 'decadência ideológica' da burguesia, clarificando sua gênese, seu desenvolvimento necessário e suas consequências. Também lhe é creditada a revelação dos nexos contemporâneos entre reação política e ideologias irracionalistas, desvelando o fenômeno - próprio da etapa imperialista - que denominou 'apologia indireta do capitalismo'."

4 A economia política clássica e o socialismo utópico, "cada qual a seu modo, eram doutrinas gerais sobre a vida social e, em consequência, haviam tratado de todos os problemas essenciais da sociedade em relação com as questões econômicas que condicionavam tais problemas. $\mathrm{O}$ nascimento da sociologia como disciplina independente faz com que o tratamento do problema da sociedade deixe de lado a sua base econômica; a suposta independência entre as questões sociais e questões econômicas constitui o ponto de partida metodológico da sociologia. Essa separação liga-se a profundas crises da economia burguesa, nas quais transparece claramente a base social da sociologia: por um lado, temos a dissolução da escola de Ricardo na Inglaterra, quando se começam a extrair consequências socialistas da teoria do valor-trabalho dos clássicos; e, por outro, temos a dissolução do socialismo utópico na França, onde se começa a buscar - ainda que somente ao nível das tentativas - o caminho da sociedade para o socialismo, o que ainda não havia constituído objeto de investigação por parte de Saint-Simon e de Fourier" (LUKÁCS, 1981, p. 132-133).

5 Segundo Hobsbawm (2010, p. 43-47): "Mil oitocentos e quarenta e oito fracassou porque ficou evidenciado que a confrontação decisiva não era entre os velhos regimes e as 'forças do progresso' unidas, mas entre 'ordem' e 'revolução social'. [...] Entre 1848 e 1849, os moderados liberais fizeram duas importantes descobertas na Europa ocidental: que a revolução era perigosa e que algumas de suas mais substanciais exigências (especialmente nos assuntos econômicos) poderiam ser atingidas sem ela. A burguesia deixara de ser uma força revolucionária."

6 "A herança teórico-cultural emancipadoraé incompatível, a partir de então, com a perspectiva de classe da burguesia-eis aí o impasse que sinaliza a crise cultural que igualmente tem por marco o ano de 1848. A sua solução histórica deu-se em duas direções: de uma parte, com a 'teoria social de Marx', os componentes emancipatórios são criticamente reelaborados numa perspectiva de classe proletária (justamente a relação de continuidade e de ruptura que Marx mantém com suas 'fontes'); de outro lado, com o 'pensamento da ordem' dividido entre um funcional, ainda que aparentemente 'radical', anticapitalismo romântico (articulado especialmente numa constelação irracionalista) e um positivismo domesticado (prisioneiro de um 'racionalismo formal'), em cujo berço nascem as ciências sociais”' (NETTO, 1998, p. 32).

7 A teoria da utilidade marginal procura dissolver todas as categorias objetivas da economia. "Nascem assim novas teorias que buscam seu único objeto nas manifestações superficiais da vida econômica (demanda, oferta, custos de produção, distribuição) e formulam pseudoleis acerca das relações subjetivistas diante de tais fenômenos (utilidade marginal). [...] Essa nova economia vulgar, tal como no Ocidente, abre assim caminho para uma ciência sociológica autônoma, separada da economia e 'complementar' a ela" (LUKÁCS, 1981, p. 138).

8 "Apenas nos tempos modernos a história conscientemente se tornou ciência, o que não ocorria antigamente, nem na intenção nem nos métodos concretos. Precisamente o tornar-se-ciência a levou a renunciar cada vez mais conscientemente, do ponto de vista metodológico, a uma universalidade. É evidente que isso tem fundamentos ideológicos. Para as classes dominantes de cada sociedade, era natural descrever ideologicamente a forma social existente como algo definitivo e que não necessitava mais de avanços [...] a ciência da história tornou-se formalmente uma ciência particular sempre mais 'exata' nas suas intenções, fator ideológico segundo o seu verdadeiro conteúdo, para tornar o processo real (mesmo no mais limitado sentido metodológico) um ponto de apoio ideológico para a conservação do meramente existente" (LUKÁCS, 2010, p. 280-281).

9 Marx eEngels (1998, p. 12) acentuam o caráter contraditório das conquistas da burguesia: "Mas a burguesia não se limitou a forjar apenas as armas que lhe trarão a morte; produziu também os homens que empurrarão essas armas - os operários modernos, os 'proletários"”.

10 De acordo com Marx: "a essência humana não é uma abstração intrínseca ao indivíduo isolado. Em sua realidade, ela é o conjunto das relações sociais” (MARX, 2009, p. 534).

11 "A divisão capitalista do trabalho, portanto, não se limita apenas a submeter a si todos os campos da atividade material e espiritual, mas se insinua profundamente na alma de cada um, provocando nela profundas deformações, que se revelam posteriormente sob variadas formas nas diversas manifestações ideológicas. A covarde submissão a esses efeitos da divisão do trabalho, a passiva aceitação destas deformações psíquicas e morais, que são, inclusive, agravadas e enfeitadas pelos pensadores e escritores decadentes, constituem um dos traços mais importantes e essências do período da decadência" (LUKÁCS, 1968, p. 63). 
12 Para Lênin (1982, p. 37), a "fase superior do capitalismo" compreende "por um lado, o capital financeiro é o capital bancário de alguns grandes bancos monopolistas fundido com o capital das associações monopolistas das indústrias, e por outro lado, a partilha do mundo é a transição da política colonial que se estende sem obstáculos a regiões ainda não apropriadas por nenhuma potência capitalista para a política colonial de posse monopolista dos territórios do globo já inteiramente repartido."

13 Na sociologia alemã, o problema essencial no período imperialista, pré-guerra, "éencontrar uma teoria acerca da gênese e da essência do capitalismo e, através de uma concepção própria, 'superar' o materialismo histórico. [...] Enquanto seguidores da teoria da utilidade marginal, a maioria dos sociólogos alemães considerava como cientificamente liquidada a teoria da mais-valia”. A sociologia alemã, analisada por Lukács, procurava elaborar metodologias para "apreender aparentemente o capitalismo sem a obrigação de enfrentar os reais problemas econômicos (antes de mais nada, a questão da mais-valia e da exploração)" (LUKÁCS, 1981, p. 149-150). Análises sobre os principais representantes da sociologia alemã (Ferdinand Tönies, Max Weber e Karl Mannheim) encontram-se em Lukács $(1959,1981)$.

14 Para Lukács (1979, p. 26-27): "não é casual que a frase sobre a ciência e a relação fenômeno-essência seja escrita por Marx no quadro de uma crítica aos economistas vulgares, em polêmica com as concepções e interpretações - absurdas do ponto de vista do ser - que estacionam nas formas fenomênicas e deixam inteiramente de lado as conexões reais".

15 Segundo Coutinho (1972, p. 14-15), o mérito essencial de Hegel, como representante da concepção de mundo moderna, reside na "sua capacidade de sintetizar e elevar a um nível superior todos os momentos progressistas do pensamento burguês revolucionário. Podemos resumi-los, esquematicamente, em três núcleos: o humanismo, a teoria de que o homem é um produto de sua própria atividade, de sua história coletiva; o historicismo concreto, ou seja, a afirmação do caráter ontologicamente histórico da realidade, com a consequente defesa do progresso e do melhoramento da espécie humana; e, finalmente, a razão dialética, em seu duplo aspecto, istoé, o de uma racionalidade objetiva imanente ao desenvolvimento da realidade (que se apresenta sob a forma da unidade dos contrários), e aquele das categorias capazes de apreender subjetivamente essa racionalidade objetiva, categorias que englobam, superando, as provenientes do 'saber imediato' (intuição) e do 'entendimento' (intelecto analítico)."

16 Retomamos, para exemplo, as análises de Marx para demonstrar o caráter histórico e transitório das relações sociais. Segundo Marx (2009, 125126), “As categorias econômicas são expressões teóricas, abstrações das relações sociais de produção. [...] As relações sociais estão intimamente ligadas às forças produtivas. Adquirindo novas forças produtivas, os homens transformam o seu modo de produçãoe, ao transformá-lo, alterando a maneira de ganhar a sua vida, eles transformam todas as suas relações sociais. O moinho movido pelo braço humano nos dá a sociedade com o suserano; o moinho a vapor dá-nos a sociedade com o capitalista industrial. Os mesmos homens que estabelecem as relações sociais de acordo com a sua produtividade material produzem, também, os princípios, as ideias, as categorias de acordo com suas relações. Assim, essas ideias, essas categorias são tão pouco eternas quanto as relações que exprimem. Elas são produtos históricos e transitórios."

17 Por modernidade social, entendemos o caráter transformador constante da ordem burguesa: "A burguesia não pode existir sem revolucionar permanentemente os instrumentos de produção - por conseguinte, as relações de produção e, com isso, todas as relações sociais. [...] A contínua subversão da produção, o ininterrupto abalo de todas as condições sociais, a permanente incerteza e a constante agitação distinguem a época da burguesia de todas as épocas precedentes. [...] Tudo o que é sólido e estável se dissolve no ar, tudo o que era sagradoé profanado e os homens são, enfim, obrigados a encarar, sem ilusões, a sua posição social e as suas relações recíprocas”(MARX; ENGELS, 1998, p. 8).

\section{Ricardo Lara}

ricbrotas@ig.com.br

Doutor em Serviço Social pela Universidade Estadual Paulista Júlio de Mesquita Filho (Unesp)

Professor do Departamento de Serviço Social (DSS) e do Programa de Pós-Graduação em Serviço Social na Universidade Federal de Santa Catarina (PPGSS-UFSC)

\section{UFSC - Programa de Pós-Graduação em Serviço Social}

Campus Universitário Reitor João David Ferreira Lima

Bairro Trindade

Florianópolis - Santa Catarina - Brasil

CEP: 88040-970 